\title{
The Prevalence of Gastrointestinal Helminths in Domestically Farmed Chicken in Van, Turkey
}

\author{
Vural DENIZHAN 1 , Ayşe KARAKUŞ2* \\ ${ }^{1}$ Öralp Vocational High School, University of V an Yuzuncu Yul, Van, Turkey \\ ${ }^{2}$ Department of Parasitology, Faculty of Veterinary Medicine, V an Yuzuncu Yal University, 65080, Van, Turkey
}

\begin{abstract}
The present study was conducted with the aim to determine the prevalence of gastrointestinal helminth in domestically farmed chicken in İpekyolu, Tuşba and Edremit districts in Van Province in Turkey. Feces of 185 chicken were examined and 78 chicken $(42.16 \%)$ yielded positive results for single species, $26(14.05 \%)$ were positive for two species, and 6 chicken $(3.25 \%)$ were positive for three species. Six helminth eggs, four nematodes and two cestodes, were detected in infected chicken feces. Those infected with single species were studied based on helminth and infection types and the rates of infection was determined as: Capillaria spp. 23 (12.50\%), Heterakis gallinarum 19 (10.32\%), Ascaridia spp. 18 (9.78\%), Raillietina spp. 8 (4.35\%), Davania proglottina 6 (3.26\%), Trichostrongylus tenuis $4(2.17 \%)$. The infection determined in feces caused by two species were Capillaria spp. + Heterakis gallinarum 10 (5.43\%), Capillaria spp. + Ascaridia spp. 8 (4.35\%), Heterakis gallinarum + Ascaridia spp. 7 (3.78\%), Raillietina spp. + Davania proglottina $1(0.54 \%)$ and infection determined in feces caused by three species were determined as Capillaria spp. + Heterakis gallinarum + Davania proglottina $4(2.17 \%)$ and Capillaria spp. + Heterakis gallinarum + Trichostrongylus tenuis $2(1.09 \%)$. The findings of the present study indicated that helminth infections were significantly prevalent in domestic chicken in Van Province in Turkey.
\end{abstract}

Keywords: Gastrointestinal Helminths, Prevalence, Chicken, Van.

\section{Van İlinde Ev Kümeslerinde Yetiştirilen Tavuklarda Gastrointestinal Helmintlerin Prevalansı}

ÖZ

Bu çalışma Türkiye'de Van ili İpekyolu, Tuşba ve Edremit ilçelerinde yetiştirilen ev tavuklarında gastrointestinal helmintlerin prevalansını belirlemek amacıyla yapılmıştır. Dışkı bakısı yapılan 185 tavuk dışkısının 78 'inde $(\% 42,16)$ tek tür, 26'sında $(\% 14,05)$ iki tür ve 6'sinda $(\% 3,25)$ üç tür olmak üzere toplam $110(\% 59,46)$ adet tavuk dışk1 örneği pozitif bulundu. Enfekte tavuk dışkılarından 4'ü nematod ve 2'si cestod olmak üzere 6 tür helmint yumurtası tespit edildi. Helmint ve enfeksiyon türlerine göre oranlarına bakıldığında tek tür ile enfekte olanlar; Capillaria spp. 23 (\%12,50), Heterakis gallinarum 19 (\%10,32), Ascaridia spp. 18 (\%9,78), Raillietina spp. 8 (\%4,35), Davania proglottina $6(\% 3,26)$, Trichostrongylus tenuis $4(\% 2,17)$, iki tür ile enfekte olanlar; Capillaria spp.+Heterakis gallinarum 10 (\%5,43), Capillaria spp.+ Ascaridia spp. 8 (\%4,35), Heterakis gallinarum + Ascaridia spp. 7 (\%3,78), Raillietina spp.+ Davania proglottina $1(\% 0,54)$, ve üç tür ile enfekte olanlar; Capillaria spp.+ Heterakis gallinarum + Davania proglottina $4(\% 2,17)$, Capillaria spp.+ Heterakis gallinarum + Trichostrongylus tenuis $2(\% 1,09)$ olarak tespit edildi. Sonuç olarak yapılan bu çalışma ile Van ili ev tavuklarında helmint enfeksiyonlarının önemli bir oranda bulunduğu tespit edildi.

Anahtar Kelimeler: Gastrointestinal Helmintler, Prevalans, Tavuk, Van.

To cite this article: Denizhan V. Karakus A. The Prevalence of Gastrointestinal Helminths in Domestically Farmed Chicken in Van, Turkey. Kocatepe Vet J. (2019) 12(4):443-447. 


\section{INTRODUCTION}

Poultry farming, especially chicken, has a highly significant place in the food industry in Turkey. The meat and egg products of poultry farming provide for a substantial portion of the animal protein requirements for humans. Particularly, low purchase power of individuals in Turkey results with an insufficiency in animal protein consumption and poultry farming can significantly close this gap since chicken is cheaper and can be processed in various ways (Ünlü 2012).

Parasitic diseases cause significant economic losses in poultry farming. Such diseases are usually subclinical without exhibiting any clinical symptoms and lack of symptoms often lead to a neglect in the diagnosis of parasitic diseases (Anders 1997). Parasitic helminth diseases are quite common especially in chicken and cause significant economic losses in poultry farming industry. The surveys conducted in Turkey reported that the prevalence of helminth in chickens were between 59.13\% and 93.44\% (Dik et al. 1988, Güçlü 1992, Altıöz 2002).

Helminths can exhibit an extensive prevalence in poultry and can cause low yield and high susceptibility to other diseases. Helminths can even cause chicken to die due to severe infections (Özdal and Ayaz 2005, Orunç and Biçek 2009).

The present study aimed to investigate the presence of helminth infections through feces examination in chicken which were farmed domestically and freerange in İpekyolu, Tuşba and Edremit districts of Van Province in Turkey.

\section{MATERIAL and METHOD}

The present study was conducted through the analysis of feces samples from 185 chicken, farmed in different coops, with a population of 15 to 30 chicken, between April 2017 and June 2018 in İpekyolu, Tuşba and Edremit districts of Van Province in Turkey. Feces samples were taken from at least 3 and at most 5 chicken that were farmed in different coops. The fresh feces samples collected from chicken were placed in the feces containers and these containers were labeled for the region, date and protocol numbers. Feces samples retrieved form chicken were examined immediately. The samples were first examined macroscopically, then native, flotation and sedimentation methods were applied to these samples. Subsequently, parasitic eggs were determined through microscopic examination at 10X and $40 \mathrm{X}$ magnifications. The samples were stored in containers in a refrigerator at $+4^{\circ} \mathrm{C}$ in $10 \%$ formaldehyde solution until their examination (Ok et al. 1997, Kaya 2003, Gökçen 2008).

\section{RESULTS}

The present study identified that 110 of the feces samples obtained from 185 chicken were infected with helminth eggs, where 78 chicken $(42.16 \%)$ were infected with single species, $26(14.05 \%)$ were with two species, and $6(3.25 \%)$ were infected with three species. Six helminth eggs, four nematodes and two cestodes, were detected in infected chicken feces. Those infected with single species were studied based on helminth and infection types and the rates of infection was determined as: Capillaria spp. 23 (12.50\%), Heterakis gallinarum 19 (10.32\%), Ascaridia spp. 18 (9.78\%), Raillietina spp. 8 (4.35\%), Davania proglottina 6 (3.26\%), Trichostrongylus tenuis 4 (2.17\%). The infection determined in feces caused by two species were Capillaria spp. + Heterakis gallinarum 10 (5.43\%), Capillaria spp. + Ascaridia spp. 8 (4.35\%), Heterakis gallinarum + Ascaridia spp. 7 (3\%), and Raillietina spp. + Davania proglottina 1 (0.54\%). Infection determined in feces caused by three species were determined as Capillaria spp. + Heterakis gallinarum + Davania proglottina $4(2.17 \%)$ and Capillaria spp. + Heterakis gallinarum + Trichostrongylus tenuis 2 $(1.09 \%)$. Table 1 presents the infection rates based on species. Once the prevalence of helminth eggs detected in chicken feces were examined, it was found that Capillaria spp. was the most common with 47 samples $(42.73 \%)$, followed by Heterakis gallinarum 42 (38.18\%), Ascaridia spp. 33 (30\%), Raillietina spp. 9 (8.18\%), Davania proglottina $11(10 \%)$, and the least common Trichostrongylus tenuis $6(5.45 \%)$. Table 2 presents the prevalence of helminths in domestically farmed chickens. 
Table 1. Prevalence of single and mixed gastrointestinal helminth infections based on feces sample examination of domestically farmed chickens

\begin{tabular}{|c|c|c|c|c|}
\hline Detected helminth species & $\begin{array}{l}\text { Infected } \\
(\mathrm{n}: 110)\end{array}$ & animals & $\begin{array}{l}\text { Total } \\
(\mathrm{n}: 185)\end{array}$ & $\begin{array}{l}\text { Infected animals }(\mathrm{n}: 110) \mathrm{n} \\
/(\%)\end{array}$ \\
\hline Capillaria spp. & & 23 & 12.5 & 20.91 \\
\hline Heterakis gallinarum & & 19 & 10.32 & 17.27 \\
\hline Ascaridia spp. & & 18 & 9.78 & 16.36 \\
\hline Trichostrongylus tenuis & & 4 & 2.17 & 3.63 \\
\hline Raillietina spp. & & 8 & 4.35 & 7.27 \\
\hline Davania proglottina & & 6 & 3.26 & 5.45 \\
\hline Capillaria spp.+ H. gallinarum & & 10 & 5.43 & 9.09 \\
\hline Capillaria spp.+ Ascaridia spp. & & 8 & 4.35 & 7.27 \\
\hline H. gallinarum + Ascaridia spp. & & 7 & 3.78 & 6.36 \\
\hline Raillietina spp.+ D. proglottina & & 1 & 0.54 & 0.90 \\
\hline spp. $+H . \quad$ gallinarum + & & 4 & 2.17 & 3.63 \\
\hline \multicolumn{5}{|l|}{ D.proglottina } \\
\hline Capillaria spp. + H. gallinarum + T. tenuis & & 2 & 1.09 & 1.81 \\
\hline Total & & 110 & 59.46 & 100 \\
\hline
\end{tabular}

Table 2. Prevalence of gastrointestinal helminth based on feces sample examination of domestically farmed chickens

\begin{tabular}{|c|c|c|c|c|c|}
\hline \multicolumn{2}{|c|}{ Detected helminth species } & \multirow{2}{*}{$\begin{array}{l}\text { Helminth species detected in infected } \\
\text { animals (n:110) } \\
47\end{array}$} & \multirow{2}{*}{$\begin{array}{l}\begin{array}{l}\text { Total } \\
(\mathrm{n}: 185)\end{array} \\
25.40\end{array}$} & \multirow{2}{*}{$\%$} & \multirow{2}{*}{$\begin{array}{l}\text { Infected animals } \\
(\mathrm{n}: 110) \mathrm{n} /(\%)\end{array}$} \\
\hline & Capillaria spp. & & & & \\
\hline \multirow{3}{*}{ 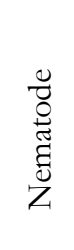 } & Heterakis gallinarum & 42 & 22.70 & & 38.18 \\
\hline & Ascaridia spp. & 33 & 17.84 & & 30.00 \\
\hline & Trichostrongylus tenuis & 6 & 3.24 & & 5.45 \\
\hline \multirow[b]{2}{*}{$\begin{array}{l}\vec{D} \\
\stackrel{0}{0} \\
\stackrel{0}{0}\end{array}$} & Davania proglottina & 11 & 5.95 & & 10.00 \\
\hline & Raillietina spp. & 9 & 8.86 & & 8.18 \\
\hline
\end{tabular}

\section{DISCUSSION}

Parasitic diseases are one of the factors that adversely affect poultry farming and cause significant death and yield losses. Parasitic diseases in poultry cannot usually be diagnosed in modern and family establishments since the diseases do not exhibit any clinical symptoms. Given that parasitic diseases are detected in a latter phase in poultry, they cause significant economic losses for poultry farmers. Helminth diseases, which also include parasitic diseases, are quite prevalent in chicken. Several species were determined in studies conducted with the aim to reveal helminth infections in chicken in Turkey and these studies reported that helminth species presented diverse prevalence (Atasever and Gümüşsay 1999, Güçlü 1995, Orunç and Biçek 2009, Dik et al. 1988, Güçlü 1992, Köse et al. 2009, AlRubai 1987).
Other studies conducted to determine the prevalence of helminth infections in chicken in different countries indicated that the prevelance was $100 \%$ in Ghana, $99.9 \%$ in India, $91 \%$ in Sudan, $90.78 \%$ in Kenya, $89.9 \%$ in North Africa, 37\% in South Africa, $16 \%$ in Iran and 1 to $3.4 \%$ in Poland (El-Khawad et al. 1977, Eslam and Anwar 1973, Fagasinski 1992, Irungu et al. 2004, Poulsen et al. 2000, Yodav and Tandon 1991, Hassouni and Belghyti 2006). Helminth infection rate was determined as $59.46 \%$ in the present study. This rate was lower than the prevalence determined in Ghana, India, Sudan, Kenya and North Africa and higher than in South Africa, Poland and Iran.

Several studies, focusing on the spread of helminth infections in chicken, were conducted in Turkey. These studies reported that the spread rate of helminth parasites in chicken and the determined species exhibited differences for different regions of Turkey. Furthermore, these studies reported that the 
spread of helminth infections in chicken in Turkey was between 16.1 and 86.5\% (Yaşarol et al. 1961, Merdivenci 1967, Al-Rubai 1987, Dik et al. 1988, Güçlü 1992, Biçek et al. 2000, Gökçen et al. 2003, Kurt and Açıc1 2003, Orunç and Biçek 2009, Köse et al. 2009, Aydin et al. 2010).

A study conducted in Turkey indicated that the prevalence of helminth infection in Ankara was $86.5 \%$ and another study reported that $48.24 \%$ of chicken farmed in official businesses, $40.85 \%$ in private businesses and $78.82 \%$ farmed in villages in Ankara were positive with helminth infections (Tolgay 1967, Al-Rubai 1987). Güçlü (1992) reported that chicken farmed in businesses around Ankara were infected with helminth by $30.76 \%$ and the rate of helminth infections in domestically farmed chicken in villages was $96 \%$. Chicken farmed in cages in Konya, Turkey were infected with various species of helminth by $11.85 \%$, whereas those farmed in environments with grid base plates were infected by $40.35 \%$ and those in family enterprises were by $60 \%$ (Dik et al. 1988).

In Afyonkarahisar province, positive infection was determined for layer hens by $11.5 \%$ and chicken farmed in villages were positive by $58 \%$, while no infection was determined in broiler chicken (Köse et al. 2009). Another study that focused on chicken farmed in villages in Hakkâri, reported that the prevalence of helminth infections was $82.14 \%$ (Aydin et al. 2010). Biçek et al. (2000) reported that helminth infections in chicken were $79.62 \%$ in Van and another study conducted by Orunç and Biçek reported that helminth infections in chicken were $52 \%$ in Van (Orunç and Biçek 2009). The present study determined that helminth infection rate in domestically farmed chicken was $59.46 \%$ and this result exhibited dissimilarities with other studies, however such discrepancy possibly stems from factors such as differences in farming environments, geographical conditions, hygiene conditions and these factors could be effective in the spread rate of helminth infections in chicken.

A study conducted in Konya, determined seven helminth species, one cestode and six nematodes, however, did not determine any trematode species. The determined helminth species were Ascaridia galli, Trichostrongylus tenuis, Subulura brumpti, Strongyloides avium, Heterakis gallinarum, Capillaria spp. and Choanotaenia infundibulum and their infection rate was 30.36\% (Dik et al. 1988). Aydin et al. (2010) reported that they identified seven helminth species, one cestode, five nematodes and one trematode, in Hakkari. Orunç and Bicek conducted a study in Van, in 2010 and reported that they identified eight helminth species, two cestodes, five nematodes and one trematode. The present study determined six helminth species, two cestodes and four nematodes, and did not determine any trematode species. Majority of the conducted studies indicated that nematode and cestode species were prevalent in poultry and trematode infections were considerably rare (Yardibi 2004). The findings of the present study based on helminth species exhibited similarities with other studies conducted in Turkey, especially due to not identifying any trematode species.

Bicek et al. (2000), conducted a study in Van and reported that the most prevalent helminth species in chicken was Capillaria spp. (22.22\%). Another study conducted by Orunç and Biçek in Van indicated that the species present in chicken were Capillaria spp. (30\%), Heterakis gallinarum (15\%), Ascaridia galli (13\%), Raillettina spp. (10\%), Davenia proglottina (8\%), Trichostrongylus tenuis (4\%), Echinostoma spp. (2\%) and Dispharynx nasuta (2\%) (Orunç and Biçek 2009). Dik et al. (1988) determined that A. galli, T. tenuis, S. brumpti, St. avium, H. gallinarum, Capillaria spp. and $C$. infundibulum were present in Konya, Turkey. Aydin et al. (2010) conducted a study in Hakkâri and reported that they identified Syngamus trachea (2.38\%), Echinostoma spp. (4.76\%), Ascaridia galli (7.14\%), Raillietina spp. (10.71\%), Trichostrongylus tenuis (11.90\%), Heterakis gallinarum (17.85\%) and Capillaria spp. $(27.38 \%)$ species. The present study, conducted in İpekyolu, Tuşba and Edremit districts of Van, determined that Capillaria spp. was the most prevalent species by 47 (42.73\%), followed by Heterakis gallinarum 42 (38.18\%), Ascaridia spp. 33 (30\%), Raillietina spp. 9 (8.18\%), Davania proglottina 11 (10\%) and Trichostrongylus tenuis was the least prevalent species by $6(5.45 \%)$.

As a result, the present study determined significant helminth infections in chicken in Van region in Turkey. It was concluded that helminth infections should be seriously taken into consideration, poultry farmers should be adequately informed, and further researches should be conducted to increase the yield and healthy farming in chickens.

\section{REFERENCES}

Al-Rubai F. The spread of Helminth infections in chickens in Ankara and its region. Master Thesis, Ankara University Institute of Health Sciences, Ankara, 1987.

Altınöz F. The Spread of Digestive System Helminths in Modern Farm Chickens in and Around Ankara. Turkiye Parazitol Derg. 2002; 26(3): 320-324.

Anders P. Helminths and helminthosis in poultry with special emphasis on Ascaridia galli in chickens. PhD Thesis. Danish Centre for Experimental Parasitology and Departmen of Veterinary Microbiology, The Royal Veterianry and Agricultural University, Copenhagen, Denmark. 1997.

Atasever A, Gümüssay KY. Pathological findings in secal coccidiosis in chickens. Turk J Vet Anim Sci. 1999; 23: 269-273. 
Aydın A, Göz Y, Değer S. Fauna of Helminth in Chickens Grown in Central Villages of Hakkari According to Their Excrement Inspections. Journal of Vet Fac of Dicle Univ. 2010; 1(1): 8-12.

Biçek K, Gül A, Değer S. Dıșkı Bakılarına Göre Van’ın Edremit İlçesindeki Ev Kümeslerinde Yetiştirilen Tavuklarda Helmint Faunasi. YYÜ Vet Fak Derg. 2000; 4(1): 269278

Dik B, Güçlü F, Gülbahçe S, Cantoray R. Konya Yöresi Tavuklarında Nematod ve Cestodların Yayılışı Üzerine Araştırmalar. Selçuk Ü Vet Fak Derg. 1988; 4(1): 269-278.

El-Khawad, El-Badawi, Eisa Am. Helminths in Chickens in Sudan. Angew Parasitol. 1977; 18 (3): 142-145.

Eslam A and Anwar M. Frequency of Helmiths in Folws in Iran. Revve Elev Med Vet Poys Trop. 1973; 26: 309-312.

Fagasinski A. Helminth parasites of domestic galliform birds in Poland. Acta Parasit Polonica 1992; 10: 347-367.

Gökçen A, Sevgili M, Altaş MG. Şanlıurfa yöresindeki tavuklarda helmintolojik araștırmalar. XVIII. Ulusal Parazitoloji Kongresi. SB03-7. 8-12 Eylül 2003, Konya.

Gökçen A. Helmintlerde tespit, boyama ve kalıcı preparat yapımı. T Parazit Der Derg. 2008; 32(2): 177-181.

Güçlü F. Helminth Fauna in chicken, turkey, ducks and geese in Ankara Region. PhD Thesis. Ankara Unıversity Instıtute of Health Sciences, Ankara, 1992.

Güçlü F. Helminth infections in chickens. Journal of the Turkish Veterinary Medical Society. 1995; 7(1): 19-22.

Hassouni T, Belghyti D. Distribution of gastrointestinal helminths in chicken farms in the Gharb RegionMorocco. Parasitol Re. 2006; 99: 181-183.

Irungu LW, Kimani RW, Kisia SM. Helmint Parasites in the Intestinal Tract to İndigenous Poultry in Parts of Kenya. JS Afr. Vet. Assoc. 2004; 75 (1); 58-59.

Kaya G. Parazitoloji Temel İlkeler ve Laboratuvar Teknikleri. Hatay: Mustafa Kemal Üniversitesi Basımevi. 2003, 4554.

Köse M, Sevimli FK, Kozan EK, Çiçek HS. Prevalence of Gastrointestinal Helminths in Chickens in Afyonkarahisar District, Turkey. Kafkas Unıv Vet Fak. 2009; 15(3): 441416.

Kurt M, Açıcı M. Samsun yöresi tavuklarda helmint enfeksiyonlarının yayılışı. XVIII. Ulusal Parazitoloji Kongresi. PB: 089. 8-12 Eylül 2003, Konya.

Merdivenci A. Türkiye'nin Marmara bölgesinde Evcil tavuk, hindi, ördek ve kazlarda görülen trematod, sestod ve nematodlara dair araştırmalar. İstanbul: İst. Üniv. Tip Fak. Yay. No: 31. 1967.

Ok ÜZ, Girginkardeşler N, Kilimcioğlu A, Limoncu E. Dışk1 İnceleme Yöntemleri. Özcel M, Altıntaş N. (Eds). Parazit Hastalıklarında Tanı. İzmir: Ege Üniversitesi Basımevi. 1997; 1-148.

Orunç Ö, Biçek K. Van Yöresi Tavuklarında Paraziter Fauna Tespiti. T Parazitol Derg. 2009; 33 (2): 162-164.

Özdal N, Ayaz E. Van'da bir tavuk otopsisinde gördüğümüz helmintler. YYÜ Vet Fak Derg. 2005; 16(2): 7-10.

Poulsen J, Permin A, Hinds O, Yelifari L, Nansen P. Prevalence and Distrubution of Gastro-İntestinal Helminths and Haemoparasites in Young Scawenging Cjickens in Upper Eastren Region of Ghana. West Africa. Prev Vet Med. 2000; 45(3-4): 237-245.
Tolgay N. Ankara ve civarı tavuklarında tesadüf edilen bağırsak nematodları üzerine sistematik araştırmalar. AÜ Vet Fak. Yayınları, 1967; 89

Ünlü H. Helminth Fauna in Chickens that is Kept in Rural Areas in Aydin. PhD Thesis. Adnan Menderes University Institute Of Health Sciences. Aydın, 2012.

Yardibi ME. Investigation of digestive system helminths in turkeys $\mathrm{PhD}$ Thesis. Ankara University Institute of Health Sciences, Ankara, 2004.

Yaşarol Ş, Ulaş H, Atılgan T. Ege'de zoosaniter durum. Bornova Vet Arşst Enst Derg. 1961; 2: 4-14.

Yodav AK, Tandon V. Helmint Parasitism of Domestic Fowl (Gallus domesticus L.) in a Suptropical High-Rainfall Area of India. Beitr Trop Landwirtsch Veterinarmed. 1991; 29 (1): 97-104. 